Мосов С. П., д-р військ. наук, професор ${ }^{1}$

1 - Національний центр управління та випробувань космічних засобів, Київ;

2 - Академія Прикордонної служби Комітету національної безпеки Республіки Казахстан, Алмати

\title{
Міжнародне співробітництво щодо забезпечення прикордонної безпеки: світова практика
}

Резюме. В умовах глобалізації світових процесів зростає кількість різного рівня завдань i проблемних ситуацій, які виникають у процесі формування відносин між країнами на міжнародній платформі. У статті систематизована світова практика міжнародного співробітництва країн в інтересах забезпечення прикордонної безпеки і визначені перспективи подальших досліджень.

Ключові слова: прикордонна безпека; міжнародне співробітництво; управління.

Постановка проблеми. На сучасному етапі суспільного розвитку відбувається активне об'єднання країн у численні союзи, асоціації, ліги й інші структури, створювані на основі різних принципів і цілей, що обумовлюється, насамперед, зростанням кількості глобальних, міжрегіональних та регіональних завдань і проблем, які виникають під час формування відносин між ними.

Це безпосереднє стосується питань забезпечення прикордонної безпеки в умовах світової глобалізації і появи таких негативних явищ, якими $\epsilon$ транскордонна та транснаціональна злочинність. У цих умовах актуалізуються питання створення міжнародних механізмів забезпечення прикордонної безпеки 3 визначенням їх особливостей в інтересах вибору моделі управління діяльністю державних органів на кордонах i їх взаємодією на міжнародному рівні.

Аналіз останніх досліджень i публікацій. Питаннями, пов'язаними 3 дослідженням міжнародного співробітництва державних органів щодо забезпечення прикордонної безпеки, займалась низка вітчизняних і зарубіжних фахівців і вчених: М. Арапов, С. Бурбела, В. Кириленко, М. Литвин, М. Міхеєнко, В. Мишаковський, Г. Молдаханова, С. Мосов, Б. Олексієнко, С. Салій, В. Серватюк, О. Трембовецький, Д. Хруст, О. Шинкарук, П. Шішолін, В. Шумов та ін.

Фахівець у сфері охорони державного кордону професор В. Серватюк частково розкрив питання міжнародного співробітництва щодо прикордонної безпеки в [1], досліджуючи зміст і сутність нової моделі охорони кордону Державною прикордонною службою України.

Практик із прикордонної безпеки П. Шішолін разом із М. Міхеєнком розглядали в [2] концептуальні засади прикордонної безпеки через призму міжнародної співпраці.

М. Литвин, який свого часу очолював Державну прикордонну службу України, у [3] розкрив питання міжнародного співробітництва в площині нашої країни і СC, узагальнив окремі напрями співпраці у межах концепції інтегрованого управління кордонами.

Значну увагу міжнародній співпраці держав 3 питань прикордонної безпеки в умовах сучасного світу приділив російський фахівець В. Шумов у [4], який запропонував загальну модель прикордонної безпеки із соціально-політичними додатками.

Забезпечення прикордонної безпеки на європейському ландшафті співробітництва України з країнами СС через упровадження сучасних прикордонних технологій досліджувалося Д. Хрустом у [5].

Питання міжнародного співробітництва розглянути відомим фахівцем у сфері охорони державного кордону професором Б. Олексієнком у [6] через механізми управління прикордонною безпекою під час проведення прикордонних операцій.

Колектив вітчизняних авторів у колективній монографії "Прикордонна безпека України: становлення, сучасний стан, проблеми і перспективи" (2018) акцентував увагу на міжнародному співробітництві щодо забезпечення прикордонної безпеки у межах європейської моделі прикордонної безпеки [7].

Міжнародний українськоказахстанський колектив авторів у [8] навів 
результати міжнародного співробітництва щодо забезпечення прикордонної безпеки у площині досліджень сутності та співвідношення категорій “виклик", “небезпека” i “загроза” в теорії прикордонної безпеки.

Водночас, дослідження зазначених авторів i авторських колективів слід розглядати як професійний ландшафт для систематизації практики міжнародного співробітництва державних органів для забезпечення прикордонної безпеки, конфігурація якого постійно змінюється.

Мета статті - систематизація світової практики міжнародного співробітництва країн в інтересах забезпечення прикордонної безпеки.

Виклад основного матеріалу. У XXI ст. в умовах досить швидких змін навколишнього світу, питання управління діяльністю державних органів на кордонах отримало нового змісту. Це обумовлено як розширенням можливостей (політичних, інструментальних та інформаційних) державних органів, які безпосередньо реалізують прикордонну політику, так i необхідністю гнучкої адаптації до досить швидких змін навколишнього світу, а також зростаючими масштабами міграційного процесу, транскордонної та транснаціональної злочинності.

У цих умовах виникає сукупність нових завдань, які державні органи раніше не вирішували або ж вирішували самостійно в досить вузьких рамках; змінюються масштаби, форми i способи дій транскордонної та транснаціональної злочинності; виникають нові взаємозв'язки між державними органами, зокрема i на міжнародному рівні; формуються нові та удосконалюються існуючі механізми управління діяльністю державних органів на кордонах і т. ін.

Проблемні питання, що виникають через це, уже неможливо вирішувати без комплексного управління діяльністю державних органів на кордонах у межах міжнародного співробітництва. Слід зазначити, що в міру його розвитку i закріплення нових відносин між його суб'єктами, роль такого управління буде 3 часом тільки зростати.

Такий підхід до управління можна охарактеризувати специфічними ознаками: своєрідні завдання, принципи і функції, що формують його як інноваційний механізм державного управління у сфері прикордонної безпеки; його ландшафтом $є$ співпраця державних органів і координація їх діяльності. Управління реалізується спеціальними суб'єктами на чотирьох рівнях: міжнародному, міждержавному, національному та прикордонному. У процесі управління забезпечується раціональний рівень прикордонної безпеки держави 3 одного боку i законні інтереси громадян 3 іншого [3].

Наочним прикладом концептуалізації ідеї комплексного управління діяльністю державних органів на кордонах є європейська концепція Integrated Border Management (далі- IBM), основна мета якої полягає в захисті прав і свобод людини, а також у запобіганні розповсюдженню транскордонній злочинності. Суть концепції викладено в трьох базових документах: Кодексі Шенгенських кордонів, Шенгенському каталозі СС, Висновках Ради СС 3 питань юстиції та внутрішніх справ 2006, 2008 і 2010 років [9, 10].

Концепція ІІМ базується на чотирирівневій моделі контролю доступу, включає заходи в третіх країнах, наприклад, у межах спільної візової політики, заходи із сусідніми третіми країнами, заходи прикордонного контролю на зовнішніх кордонах, аналіз ризиків, заходи в Шенгенській зоні та заходи щодо репатріації.

Ідея концепції IBM полягає в посиленні захисту зовнішніх кордонів і створенні умов для ефективного обміну інформацією про можливі небезпеки та загрози безпеці між державами-членами $\mathrm{CC}$, у спрямованості, таким чином, основних зусиль на розвиток можливостей тих країн, ділянки державного кордону яких збігаються із зовнішнім кордоном ЄC.

Головний зміст концепції IBM полягає в національній i міжнародній координації та співпраці між органами влади і відомствами, які беруть участь в охороні та контролі кордонів, а також у сприянні торгівлі для забезпечення ефективного та скоординованого управління діяльністю державних органів на кордонах для створення відкритих, контрольованих і надійних кордонів. До того ж ключовим аспектом співпраці на міжнародному багатосторонньому рівні $\epsilon$ обмін інформацією [11].

У межах ЄС створено Європейське агентство 3 управління оперативним співробітництвом на зовнішніх кордонах держав-членів СC - Frontex, яке формує загальноєвропейську ситуаційну картину i 
загальну прикордонну розвідувальну ситуацію (з акцентом на райони за межами Шенгенської зони і зони (C). Метою діяльності Frontex $\epsilon$ забезпечення еквівалентного рівня захисту за всім протягом зовнішніх кордонів СС. Агентство вирішує такі завдання, як: координація співпраці між агентствами під час управління зовнішніми кордонами; проведення аналізу ризиків; проведення досліджень у сфері контролю за зовнішнім кордоном; допомога державам-членам СС під час підготовки кадрів; забезпечення державчленів $\mathrm{EC} \mathrm{необхідною} \mathrm{підтримкою} \mathrm{під} \mathrm{час}$ організації спільних операцій. До того ж організація контролю державних кордонів є суверенним завданням кожної з держав-членів EC $[12,13]$.

Низка вчених і фахівців з прикордонної тематики переводять словосполучення "Integrated Border Management" як “інтегроване управління кордонами" [3], “комплексне управління кордонами” [14] або “скоординоване управління кордонами" [13], що не відповідає смисловій суті словосполучення.

Згідно 3 визначенням, під терміном “державний кордон" розуміється лінія i вертикальна площина, що проходить по ній, які визначають межі території держави (суші, вод, надр, повітряного простору) і просторову межу дії державного суверенітету країни [15], тобто це фактично стаціонарний об'єкт, яким неможливо управляти.

Управління починається тоді, коли в будь-яких взаємозв'язках, відносинах, явищах або процесах присутні свідомі основи; воно існує в межах взаємодії людей, у межах суб'єктивного фактора i виступає як самоврядування, в основі якого лежить принцип зворотного зв'язку $[16,17]$.

3 огляду на суть терміна “управління", словосполучення "Integrated Border Management" слід трактувати як “комплексне управління діяльністю державних органів на кордонах".

Європейська модель комплексного управління діяльністю державних органів на кордонах в офіційному трактуванні як “інтегроване управління кордонами” реалізується, крім ЄС, такими суміжними з СС країнами, як Молдова, Україна і Білорусь за підтримки консультативно-технічного органу, який фінансується СС у межах Свропейського інструменту добросусідства і партнерства EUBAM.

Упроваджується така модель у різному ступені в низці інших держав-учасників програмної ініціативи СС "The Eastern Partnership", зокрема у Вірменії, Азербайджані та Грузіï $[11,18]$.

Щодо Центральної Азії з ініціативи СС розроблена і діє програма Border Management Programme in Central Asia (далі - BOMCA), реалізація якої спрямована на підвищення потенціалу та інституційний розвиток, розвиток торговельних коридорів, поліпшення систем управління діяльністю державних органів на кордонах i викорінення торгівлі наркотиками в Центральноазіатському регіоні. Загальна мета ВОМСА - підвищення ефективності та результативності управління діяльністю державних органів на кордонах у Центральній Азії шляхом впровадження передових елементів комплексного управління та надання сприяння урядам у розвитку та реформуванні державного управління міграційними процесами, у розвитку політики мобільності та сприяння торгівлі, у розширенні можливостей прикордонних i міграційних відомств i, таким чином, сприяння зміцненню безпеки та економічному розвитку на національному та регіональному рівнях [19].

До країн-партнерів програми входять: Республіка Казахстан, Республіка Киргизстан, Республіка Таджикистан, Туркменістан і Республіка Узбекистан [13, 20]. ЄС активно заохочує ці держави у їх прагненні розвивати національні підходи до підвищення якості управління діяльністю державних органів на кордонах на основі моделі IBM.

Слід зазначити, що європейська модель комплексного управління діяльністю державних органів на кордонах не створює системних протиріч між національними i союзними (колективними) інтересами. За основними позиціями вона зручна для застосування у двосторонньому та багатосторонньому (регіональному, субрегіональному) форматах. Це один з дієвих аргументів на користь розвитку діалогу 3 питання перспективності впровадження європейського досвіду в інших державах 3 урахуванням їх національних інтересів.

Для вирішення питань охорони зовнішніх кордонів держав-членів СНД і забезпечення стабільного положення на них створена i успішно функціонує Рада командувачів прикордонними військами (далі- РКПВ), яка є головним органом Ради глав держав СНД 3 питань координації взаємодії прикордонних відомств державучасниць СНД у сфері забезпечення узгодженої прикордонної політики на 
зовнішніх кордонах держав-учасниць СНД [21].

Основу діяльності РКПВ складають такі напрями: координація та узгодження зусиль прикордонних військ у галузі охорони зовнішніх кордонів і економічних зон, а також забезпечення стабільності на них; розвиток дружніх зв'язків між прикордонними військами держав-учасниць СНД; сприяння розвитку та зміцненню прикордонних військ держав-учасниць СНД шляхом зближення національного законодавства 3 питань кордонів та їх охорони, взаємного обміну інформацією, співпраці у сфері військовотехнічної політики та підготовки кадрів.

у межах Євразійського економічного співтовариства (далі - СврАзЕС) заснована i цілеспрямовано функціонує Рада 3 прикордонних питань (далі -РПП) державчленів СврАзЕС, що створена для реалізації цілей і завдань у сфері забезпечення загальної системи безпеки і охорони зовнішніх кордонів СврАзЕС, здійснення координації та взаємодії прикордонних відомств держав-учасниць ЄврАзЕС i проведення узгодженої прикордонної політики [22].

РПП здійснює свою діяльність за такими напрямами: підготовка пропозицій щодо формування узгодженої прикордонної політики та iï реалізації; захист інтересів держав-членів ЄврАзЕС на їх зовнішніх кордонах; зміцнення й облаштування зовнішніх кордонів СврАзЕС; створення механізму координації дій під час зміцнення загальної системи безпеки й охорони зовнішніх кордонів; розроблення та реалізація узгоджених (спільних) заходів боротьби 3 транскордонною організованою злочинністю і тероризмом, незаконною міграцією громадян третіх країн, проникненням зброї, наркотичних засобів та іншої контрабанди на територію держав-членів СврАзЕС; формування нормативно-правової бази ЄврАзЕС з прикордонних питань.

Цілі, принципи, напрями i форми співпраці держав-членів СврАзЕС з підтримки режиму зовнішніх кордонів викладені в "Положенні про основні принципи, напрями та форми співробітництва держав-членів Євразійського економічного співтовариства 3 підтримки режиму зовнішніх кордонів” [23].

У реалізації комплексного управління діяльністю державних органів на кордонах в Азії, Океанії та Африці особливість виявляється в тому, що основним напрямом розвитку в цих макрорегіонах світу $\epsilon$ спрощення торгівлі шляхом гармонізації процедур контролю i застосування інформаційних технологій [13].

На африканському континенті була поширена концепція "Coordinated Border Management" (далі - CBM) [24], що являє собою комплекс заходів, спрямованих на оптимізацію i координацію функціонування державних органів на кордонах, контроль інформаційних i фізичних потоків товарів i пасажирів, які перетинають кордони. До сфери функціонування СВМ віднесено: обмін інформацією; спільне використання об'єктів інфраструктури, міжвідомча співпраця, делегування адміністративних повноважень $[13,25]$.

Основною метою реалізації моделі СВМ для більшості країн Африки $є$ розвиток інфраструктури пунктів перетину кордону, за рахунок чого саме і відбувається спрощення процедур торгівлі, а також скорочення витрат країн.

Прикладом

міжнародного прикордонного співробітництва $є$ організація контролю на спільному кордоні Норвегії, Швеції і Фінляндії - сусідніх держав, які уклали угоду про створення прикордонного пункту "однієї зупинки" [13, 14]. Основною ідеєю такого співробітництва $\epsilon$ те, що перевірки $\mathrm{i}$ формальності мають здійснюватися в одному місці, і таким чином, щоб митні відомства однієї сторони могли контролювати сплату митних платежів, дотримання формальностей, що стосуються імпорту та експорту, а також інших митних правил від імені митних відомств іншої сторони. Митні відомства в пунктах пропуску через норвезько-шведський i норвезькофінський кордони користуються спільною інфраструктурою, співробітники кожної країни працюють на загальній території, що дає змогу їм не засновувати митні пункти пропуску по обидва боки кордону.

Сучасний стан ситуації, пов'язаної 3 викликами та загрозами, насамперед, міжнародним тероризмом, транскордонною організованою злочинністю, незаконною міграцією та контрабандою, спонукає світову спільноту, як і безпосередньо Україну, до пошуку консолідованих державноуправлінських рішень 3 питань міжнародної співпраці щодо забезпечення прикордонної безпеки. Зважаючи на це, Державна прикордонна служба України у межах європейських програм співробітництва тісно й успішно співпрацює з європейською Агенцією 3 питань управління оперативним співробітництвом на зовнішніх кордонах 
країн-учасниць Євросоюзу FRONTEX, яка створена i функціонує на підставі розпорядження Ради ЄС з 2010 року [3,7]. Європейську інтеграцію визначено одним 3 головним пріоритетних завдань України, що вимагає від прикордонного відомства, як і від інших державних структур, цілеспрямованої адаптації до європейської моделі інтегрованого управління кордонами.

Висновки. На підставі розглянутих підходів до реалізації взаємодії на міжнародному рівні державних органів щодо забезпечення прикордонної безпеки можна дійти таких висновків:

зростання кількості глобальних, міжрегіональних, регіональних завдань i проблем, що виникають у процесі формування відносин між країнами, активізує світовий процес інтеграції та призводить до їх об’єднання в численні союзи, асоціації, ліги та інші структури, що створюються на підставі різних принципів і цілей;

комплексне управління діяльністю державних органів на кордонах стає важливим напрямом у міжнародному прикордонному співробітництві країн в інтересах забезпечення як національної, так i транснаціональної безпеки, даючи змогу вибудовувати раціональну модель взаємин на суміжних і зовнішніх кордонах різних держав і спілок;

розвивається процес попередження виникнення проблемних ситуацій на міжнародному рівні, пов'язаних 3 транскордонною та транснаціональною злочинністю, а також міграцією, шляхом уніфікації та впровадження випробуваних моделей комплексного управління діяльністю державних органів на кордонах з урахуванням національних особливостей країн i формуванням необхідного рівня технічного та кадрового забезпечення;

забезпечення ефективного та скоординованого управління діяльністю державних органів на кордонах 3 метою створення відкритих, контрольованих і надійних кордонів на світовому просторі здійснюється шляхом національної та міжнародної координації i співпраці між органами влади та відомствами, які беруть участь в охороні та контролі кордонів, а також у сприянні процесам торгівлі.

Актуальним напрямом подальших досліджень слід вважати дослідження особливостей механізмів прикордонної взаємодії суміжних країн щодо забезпечення прикордонної безпеки.

\section{СПИСОК ВИКОРИСТАНОЇ ЛІТЕРАТУРИ}

1. Серватюк В. М. Зміст та сутність нової моделі охорони кордону Державною прикордонною службою України. Прикордонник Украӥни. 2003. Спеціальний випуск. С. 4.

2. Шишолін П. А., , Михеєнко М. М. Прикордонна безпека України: концептуальні засади. Науковий вісник Прикордонних військ : науковопрактичний альманах. 2002. № 1. С. 3-5.

3. Литвин M. M. Інтегроване управління кордонами. Київ : ДПСУ, 2011. 542 с.

4. Шумов В. В. Пограничная безопасность как ценность и общественное благо. Математические модели. Москва : ЛЕНАНД, 2015. 184 с.

5. Хруст Д. В. Основні напрямки забезпечення подальшого впровадження в практику охорони державного кордону сучасних прикордонних технологій. Збірник наукових пращь. Хмельницький, 2009. № 49/1. Ч. II. C. 51-54.

6. Олексієнко Б. М., Механізми управління прикордонною безпекою при проведенні прикордонних операцій. Збірник наукових праиџь. Хмельницький, 2010. № 16. Ч. І. C. 85-93.

7. Прикордонна безпека України: становлення, сучасний стан, проблеми і перспективи : кол. монографія / О. М. Шинкарук, С. П. Мосов, В. А. Кириленко, $\quad$ О. Г. Трембовецький, С. В. Бурбела. Хмельницький : НАДПСУ, 2018. $188 \mathrm{c}$.

8. Мосов С. П., Салий С. М., Молдаханова Г., Арапов М. К. Сущность и соотношение категорий “вызов”, “опасность” и “угроза" в теории пограничной безопасности. Научный аспект. 2019. № 3. С. 652-659.

9. Niculiu A. European Integrated Border Management. URL: https:// eapmigrationpanel.org/sites/default/files/files/1._dg home_european_ibm.pdf (дата звернення: 10.04.2020).

10. Integrated Border Management. URL: http://eubam.org/what-we-do/integrated-bordermanagment/ (дата звернення: 10.04.2020).

11. Документ для дискуссии на Встрече Панели по вопросам интегрированного управления границами. 27-28 сентября 2018 г. URL: https://eapmigrationpanel.org/ sites/default/files/files/discussion_paper_ibm_rusfina 1.pdf (дата звернення: 10.04.2020).

12. European Border and Coast Guard Agency (Frontex). URL: https://europa.eu/ europeanunion/about-eu/agencies/frontex_en (дата звернення: 10.04.2020).

13. Скоординированное управление границей: международные стандарты и правоприменительная практика : кол. монография / О. Г. Боброва, А. Ю. Кожанков, Д. Г. Коровяковский, $\quad$ Т. С. Ненадышина, С. О. Шохин ; под ред. д-ра юрид. наук, проф. С. О. Шохина, канд. юрид. наук 


\section{МІЖНАРОДНЕ СПІВРОБІТНИЦТВО У ВОСННІЙ СФЕРІ}

А. Ю. Кожанкова. Москва : Прометей, 2017. $192 \mathrm{c}$.

14. Анишевски C. Комплексное управление границей - концепция. URL: http://www.wcoomd.org/-/media/wco/public/ru/pdf/ topics/research/activities-and-programmes/ coordinated-border-management_rus.pdf?la=en (дата звернення: 10.04.2020).

15. Пограничный словарь : Академия Федеральной ПС РФ, 2002. 260 c.

16. Мосов С. П., Нижник Н. Р. Теоретичні аспекти державного управління : монографія. Чернівці : Технодрук, 2011. 248 с.

17. Мескон М. Х., Альберт М., Хедоури Ф. Основы менеджмента ; пер. с англ. Москва : Дело, 1992. 702 c.

18. The Eastern Partnership. URL: https://www. euneighbours.eu/en/policy/ eastern-partnership (дата звернення: 10.04.2020).

19. BOMCA. Overview. URL: https://www.bomcaeu.org/en/programme/ overview (дата звернення: 10.04.2020).

20. BOMCA. Partner Countries. URL: https://www. bomca-eu.org/en/ (дата звернення: 10.04.2020).

21. Положение о Совете командующих
Пограничными войсками (с изменениями). URL: http://www.skpw.ru/sections/skpw/state.html (дата звернення: 10.04.2020).

22. Положение о Совете по пограничным вопросам государств-членов Евразийского экономического сообщества. URL: http://www.evrazes.com/ about/vspom/ comission/view/13 (дата звернення: 10.04.2020).

23. Положение об основных принципах, направлениях и формах сотрудничества государств-членов Евразийского экономического сообщества по поддержанию режима внешних границ. URL: http://www.evrazes.com/about/ vspom/ comission/ view/13 (дата звернення: 10.04.2020).

24. Coordinated Border Management. URL: http://www.wcoomd.org/ en/topics/ facilitation/ activities-and-programmes/coordinated-bordermanagement.aspx (дата звернення: 10.04.2020).

25. Draft African Union Strategy for Enhancing Border Management in Africa. URL: http://www.peaceau.org/uploads/AU-DSD-

WORKSHOP-MARCH-2013/Border-Programmedocs/AU-BM-Strategy-Revised\%20Draft.pdf (дата звернення: 10.04.2020).

Стаття надійшла до редакційної колегії 28.05.2020

\section{International cooperation on border security: world practice}

\section{Annotation}

The article systematizes the world practice of international cooperation in the interests of border security under the conditions of development of world processes globalization, which leads to an increase in the number of different levels of tasks and problems that arise in the formation of relations between countries on an international platform. Emphasis is placed on the expediency and features of the international experience of integrated management of state bodies at borders in the framework of international cooperation. The European model of management is analyzed, which has prospects for its implementation in a number of European countries that are not part of the European Union, as well as in the countries of Central Asia. Emphasis is placed on the incorrect terminological use of such phrases as "integrated border management", "complex border management" or "coordinated border management", which does not correspond to the semantic essence. A new phrase was introduced - "integrated management of state bodies at borders". Models of international cooperation are analyzed on the examples of the Eurasian Economic Community member states and the CIS member states, African countries and the Scandinavian countries in the issues of integrated management of state bodies at the borders. Conclusions are made and prospects of further researches are defined.

Keywords: border security; international cooperation; management. 